\title{
INTRANASAL SENSITIZATION WITH Blomia tropicalis ANTIGENS INDUCES ALLERGIC RESPONSES IN MICE CHARACTERIZED BY ELEVATED ANTIGEN-SPECIFIC AND NON-SPECIFIC SERUM IgE AND PERIPHERAL BLOOD EOSINOPHIL COUNTS
}

\author{
Fumiko TAKEDA(1), Takeshi ARAKAWA(2), Hiromu TOMA(1), Akira ISHII(3) \& Yoshiya SATO(1)
}

\begin{abstract}
SUMMARY
In order to evaluate the potential allergenicity of Blomia tropicalis $(\mathrm{Bt})$ antigen, IgE production of both specific and non-specific for $\mathrm{Bt}$ antigen was monitored in $\mathrm{BALB} / \mathrm{c}$ mice after exposure to the antigen by nasal route. It was evidenced that $B$. tropicalis contains a functional allergen in its components. The allergenic components, however, when administered intranasally without any adjuvant, did not function to induce IgE response within a short period. On the other hand, intranasal inoculation of Bt antigens augmented serum IgE responses in mice pretreated by a subcutaneous priming injection of the same antigens. Inoculation of Bt antigen without subcutaneous priming injections induced IgE antibody production only when the antigen was continuously administered for a long period of over 24 weeks. Even when the priming injection was absent, the Bt antigen inoculated with cholera toxin (CT) as a mucosal adjuvant also significantly augmented the Bt antigen-specific IgE responses depending on the dose of CT co-administered. The present study also demonstrated that Bt antigen/CT-inoculated mice showed increased non-specific serum IgE level and peripheral blood eosinophil rates without noticeable elevations of the total leukocyte counts. The immunoblot analysis demonstrated 5 main antigenic components reactive to $\mathrm{IgE}$ antibodies induced. These components at about 44-64 $\mathrm{kDa}$ position were considered to be an important candidate antigen for diagnosis of the mite-related allergy.
\end{abstract}

KEYWORDS: Mite; Blomia tropicalis; Intranasal sensitization; Mucosal adjuvant.

\section{INTRODUCTION}

Blomia tropicalis VAN BRONSWIJK et al., $1973^{29}$ is a species of house dust mites which belongs to the family Glycyphagidae. The mite has been ubiquitously found in common houses in tropical and subtropical areas ${ }^{1,2,7,10,21,23}$. Although there have been a few reports indicating the scarce distribution of the genus Blomia in mainland of $\operatorname{Japan}^{18,20}$, the authors and other investigators have recently reported that $B$. tropicalis is one of the major mite species found in Okinawa, a subtropical prefecture of Japan ${ }^{14,26,27}$.

B. tropicalis, as well as Dermatophagoides pteronyssinus, has been implicated as one of the important causative agents of mite-related allergic diseases in many countries in South America and Southeast Asia, because patients with typical allergic symptoms, such as asthma, atopic dermatitis and rhinitis, in these areas are known to show positive skin responses and high levels of serum IgE against antigens of B. tropicalis tr, $^{3,8,13,15,19,25}$. These facts strongly suggest that $B$. tropicalis contains allergen(s) with the potential to induce systemic $\operatorname{IgE}$ responses in humans ${ }^{4,5}$. However, there were few experimental studies to demonstrate the Bt-specific $\mathrm{IgE}$ production by antigen exposure ${ }^{24}$. In the present study, the authors tried to demonstrate Bt antigen-specific serum IgE production in mice exposed to $\mathrm{Bt}$ antigen by nasal route.

\section{MATERIALS AND METHODS}

Mice: Male BALB/c mice, 4-6 weeks old, were purchased from Seac Yoshitomi Ltd. (Fukuoka, Japan) and kept in the animal care facility throughout the course of experiments, according to the guidelines for animal experimentation in the University. The protocols for the experiment were also approved by the Committee for animal care and use in the University.

Extraction of mite antigen: $B$. tropicalis collected from dust in an old Okinawan house was cultured to propagate in a food medium consisting of an equivalent mixture of rodent chow (Clea Rodent Diet CE-2, Clea Japan Inc., Tokyo, Japan) and dry yeast (Ebiosu, Tanabe Seiyaku Co., Osaka, Japan) at $28{ }^{\circ} \mathrm{C}$ with $85 \%$ humidity. After 2 months of culturing, the propagated mites were collected using a modified Tullgren apparatus. The antigens were extracted from the mites essentially according to the method of STANALAND et al. ${ }^{25}$. Briefly, the mites were treated with an excess of cold diethylether for delipidization for 4 


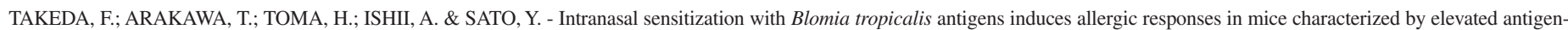
specific and non-specific serum IgE and peripheral blood eosinophil counts. Rev. Inst. Med. trop. S. Paulo, 46(1):1-8, 2004.

$\mathrm{hr}$ in Erlenmeyer flask without agitation, and dried at room temperature after the diethylether was removed. The mites were then homogenized with a glass homogenizer and the homogenates were stirred to extract antigens for $24 \mathrm{hr}$ at $4{ }^{\circ} \mathrm{C}$ in $\mathrm{PBS}(\mathrm{pH} 7.2)$ containing $0.02 \% \mathrm{NaN}_{3}$ as a disinfectant. The extract was then centrifuged at $10,000 \mathrm{rpm}$ for $30 \mathrm{~min}$ and the supernatant fluid was recovered as the source of Bt antigen. Protein concentration in the extract was measured by the Bradford method (Protein assay, Bio-Rad Lab., USA) and the antigen solution was stored at $-85^{\circ} \mathrm{C}$ until use.

The extracts from other mite species, Dermatophagoides pteronyssinus (Dp) and chironomid species, Tokunagayusurika akamusi (Ta) and Chironomus yoshimatsui (Cy), were also served in the present study. D. pteronyssinus were cultured similarly by the author but chironomid species were kindly supplied by Dr. Matsuoka, Jichi University, Tochigi, Japan.

Antigen sensitization of mice: The intranasal sensitization of mice with Bt antigen was performed by dripping a drop (approximately 10 $\mu \mathrm{l})$ of the Bt antigen solution $(4.0 \mathrm{mg} / \mathrm{ml})$ into the nasal cavity of mice. In order to prime immune responses generally, subcutaneous injections of Bt antigen emulsified in an equal volume of Freund's complete adjuvant (Difco Lab, USA), twice at an interval of 7 days, was performed in a group of mice prior to the intranasal inoculation. The effect of mucosal adjuvant on induction of Bt-antigen specific IgE was also evaluated in another group of mice inoculated intranasally with the mixture of Bt antigens and cholera toxin (CT; Sigma Chemical Co., USA). The mice which were administered PBS, instead of Bt antigen, were served as the control for each experiment.

Mice were periodically bled by tail vein puncture or cardiac puncture 2-7 days after the final inoculation, and the sera were separated to store at $-85^{\circ} \mathrm{C}$.

Passive cutaneous anaphylaxis (PCA): PCA was applied to detect Bt-antigen specific IgE response. Briefly, sensitized or control mouse sera were diluted five-fold in physiological saline and $50 \mu \mathrm{l}$ of the diluted sera was injected intradermally on a shaved back of a male Wistar rat (Seac Yoshitomi. Ltd., Fukuoka, Japan). Forty-eight hours later, $1.0 \mathrm{ml}$ of Bt antigen solution $(1.0 \mathrm{mg} / \mathrm{ml})$ containing $1.0 \%$ Evans blue was injected via tail vein into the rat. Blue spots appeared $30 \mathrm{~min}$ later on the rat's backside skin, were observed, and the diameter of the blue spots that measured over $5 \mathrm{~mm}$ in diameter were considered positive results in the PCA test.

ELISA for specific IgE measurement: IgE antibody levels against $\mathrm{Bt}$ antigen were determined by indirect ELISA method as follows: $\mathrm{Bt}$ antigen was dissolved at a protein concentration of $100 \mu \mathrm{g} / \mathrm{ml}$ in $50 \mathrm{mM}$ carbonate buffer, $\mathrm{pH} 9.65$, and $100 \mu \mathrm{l}$ of this was applied to each well of a polystyrene microplate (MS-8496F, Sumitomo Bakelite Co., Tokyo, Japan). The microplate was incubated first for $2 \mathrm{hr}$ at $37^{\circ} \mathrm{C}$ to sensitize the well surface with Bt antigen and subsequently for overnight at $4{ }^{\circ} \mathrm{C}$. After removal of the contents, the wells were further treated with $300 \mu \mathrm{l}$ of $2.0 \%$ bovine serum albumin (BSA; Sigma Chemicals Co., USA) in PBS for 2 $\mathrm{hr}$ at $37^{\circ} \mathrm{C}$ to block the remaining binding sites on the well surface. After washing three times with $0.05 \%$ Tween 20 -PBS using a plate washer (Immuno Wash Model 1575, Bio-Rad Lab., Italy), the wells were filled with $100 \mu \mathrm{l}$ of mouse test sera diluted 10-fold in 1.0\% BSA-PBS, and incubated for $2 \mathrm{hr}$ at $37^{\circ} \mathrm{C}$ followed by overnight incubation at $4{ }^{\circ} \mathrm{C}$. After similar washing, $100 \mu \mathrm{l}$ of rat anti-mouse IgE monoclonal antibodies (affinity purified; IM2992, Immunotech, France), diluted in 1:300, was applied to each well. After incubation for $2 \mathrm{hr}$ at $37{ }^{\circ} \mathrm{C}$, the wells were washed and further incubated with $100 \mu \mathrm{l}$ of rabbit anti-rat IgG antibodies conjugated with horseradish peroxidase (HRP) (SAB-200; StressGen Biotechnologies Corp., Canada), diluted in 1:300, for $2 \mathrm{hr}$ at $37^{\circ} \mathrm{C}$. After washing wells, $100 \mu \mathrm{l}$ of a $0.01 \%$-orthophenylene-diamine solution was added to each well as substrate of HRP, and the color was allowed to develop for $30 \mathrm{~min}$ at room temperature. The reaction was stopped by adding $10 \mu \mathrm{l}$ of $4.0 \mathrm{M} \mathrm{H}_{2} \mathrm{SO}_{4}$, and absorbance (OD) was read at $490 \mathrm{~nm}$ using a Microplate Reader Model 550 (Bio-Rad Lab., Italy).

Total serum IgE measurement: Total serum IgE was measured according to the manufacturer's instructions using the mouse $\operatorname{IgE}$ measurement kit (Yamasa EIA, Yamasa-syoyu Co., Tokyo, Japan). The wells of a microplate coated with anti-mouse IgE monoclonal antibodies were allowed to capture $\operatorname{IgE}$ in the test serum by incubation with $100 \mu \mathrm{l}$ of 1:24 diluted test sera for $30 \mathrm{~min}$ at room temperature. After washing, the wells were further incubated with HRP labeled anti-mouse IgE for $30 \mathrm{~min}$ at room temperature. The wells were finally filled with substrates and allowed to develop colors for $30 \mathrm{~min}$. The reaction was stopped by addition of a $2.0 \mathrm{~N} \mathrm{HCl}$ solution ( $100 \mu \mathrm{l}$ for each well). Mouse IgE isotype standard solutions were used to construct the standard curve (10-500 $\mathrm{ng} / \mathrm{ml}$ ) and total serum $\mathrm{IgE}$ levels were calculated from the standard curve, based on the optical density measured at $450 \mathrm{~nm}$.

Total leukocyte count and eosinophil rate: Total leukocyte numbers in peripheral blood were counted according to the standard method using Neubauer's hemocytometer (Erma, Tokyo, Japan). Thin blood films smeared on a glass slide were stained with Giemsa's staining solution and the percentages of eosinophils were calculated by counting the number of eosinophil in a total of 200 leukocytes. The measurements were repeated twice and the average was calculated.

Immunoblotting: The antigen components reactive to anti-Bt $\operatorname{IgE}$ antibody were identified by Western blot analysis using the mouse sera sensitized with Bt antigen. Briefly, the crude extract from B. tropicalis $(20 \mu \mathrm{g})$ was applied on a $12.5 \%$ SDS-PAGE gel and electrophorezed for $2 \mathrm{hr}$ at $120 \mathrm{~V}$ in the presence of 5\% 2-ME (2-mercaptoethanol, Nakarai, Kyoto, Japan). The polypeptides separated in the gel were transferred electrophoretically onto a nitrocellulose membrane (BA-S 83, Sehleich\&Schuell, Germany) for $1 \mathrm{hr}$ at $60 \mathrm{~V}$. The blotted membrane was soaked in $1.0 \%$ BSA solution in PBS containing $0.05 \%$ Tween-20 to block binding sites on the membrane. Then, the membrane was well incubated with 25 -fold diluted mouse serum for $1 \mathrm{hr}$ at $37^{\circ} \mathrm{C}$. After washing three times with PBS-Tween 20, the membrane was further incubated with rat anti-mouse IgE monoclonal antibodies (affinity purified; IM2992, Immunotech, France) for $1 \mathrm{hr}$ at $37^{\circ} \mathrm{C}$. After washing similarly, the membrane was treated with HRP-conjugated rabbit antirat IgG antibodies (SAB-200; StressGen Biotechnologies Corp., Canada) for $1 \mathrm{hr}$ at $37^{\circ} \mathrm{C}$, and the color was allowed to develop by soaking the membrane in a diaminobenzidine substrate solution (DAB; D-4418, Sigma, Germany).

Statistics: Statistical analysis was performed by computer software (StatView-J4.11). ANOVA and Fisher's PLSD were used to analyze differences in IgE levels, leukocyte counts and eosinophil rates. A $p$ value less than 0.05 was considered to be statistically significant. 
Table 1

PCA responses in mice inoculated with Bt antigens with or without subcutaneous priming injections

Inoculation scheme s.c. Bt antigen priming
PCA response to Bt antigen

(Number of mice with positive response)

\begin{tabular}{|c|c|c|c|}
\hline & & & \\
\hline & & $\mathrm{Bt}$ & PBS \\
\hline 10 times (5-day interval) & - & $0 / 5$ & $0 / 5$ \\
\hline 10 times (5-day interval) & + & $4 / 5$ & $3 / 5$ \\
\hline 25 times (2-day interval) & + & $5 / 5$ & $5 / 5$ \\
\hline
\end{tabular}

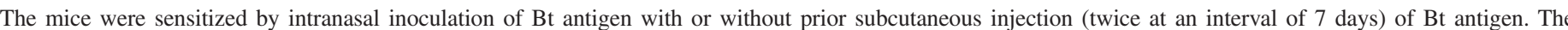

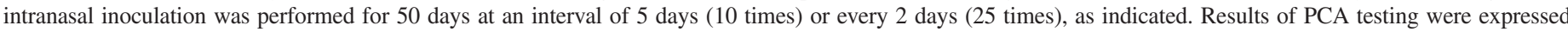
in number of mice whose sera indicated a spot larger than $5 \mathrm{~mm}$ (Five mice were used in each group).

\section{RESULTS}

Induction of serum IgE by inoculation of Bt antigen: Results of the PCA test in mice variously exposed to Bt antigen for 50 days are summarized in Table 1 . The mice inoculated intranasally with Bt antigen without priming immunization were completely unresponsive in the PCA test. However, when mice were pretreated with a subcutaneous injection of the Bt antigen, the PCA response became positive in many mice. The PCA responses after the priming subcutaneous injection were generally stronger in mice followed with a subsequent intranasal inoculation of $\mathrm{Bt}$ antigen, as represented in Fig.1.

The effect of co-administration of mucosal adjuvant on the induction of Bt-specific IgE response was monitored in the other groups of mice and the results are summarized in Table 2. Co-administration of cholera toxin $(\mathrm{CT})$ as a mucosal adjuvant produced strong PCA responses in mice that received $\mathrm{Bt}$ antigen without priming immunization, although the mice received $\mathrm{Bt}$ antigen or $\mathrm{CT}$ alone failed to respond in the PCA test (Fig. 2). When CT was administered as a mucosal adjuvant, the intranasal inoculation of $\mathrm{Bt}$ antigen induced specific $\mathrm{IgE}$ responses in a

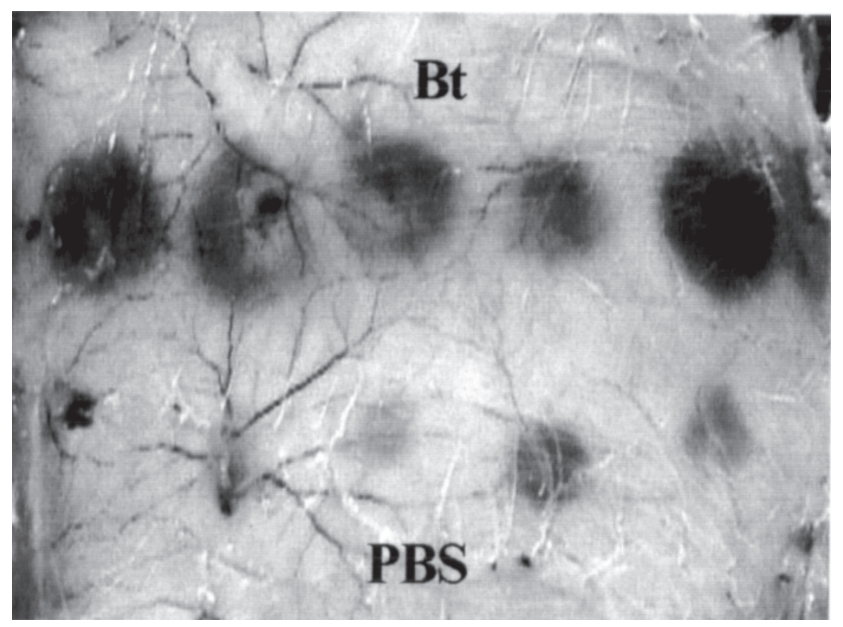

Fig. 1 - PCA responses in mice inoculated with Bt antigen following the subcutaneous priming immunization. Upper five spots indicated responses in mice that received intranasal inoculation of $\mathrm{Bt}$ antigen after the priming immunization. Lower five spots indicated control responses in mice that received PBS intranasally after the priming immunization. The intranasal inoculation was performed for 50 days at an interval of 2 days ( 25 times).
Table 2

PCA responses in mice inoculated with Bt antigens in the presence or absence of mucosal adjuvant $\mathrm{CT}$

\begin{tabular}{lc}
\hline $\begin{array}{l}\text { Sensitizing } \\
\text { inoculation }\end{array}$ & $\begin{array}{c}\text { PCA response } \\
\text { (Number of mice with positive response) }\end{array}$ \\
\hline PBS & $0 / 4$ \\
Bt $20 \mu$ g only & $0 / 4$ \\
CT $10 \mu \mathrm{g}$ only & $0 / 4$ \\
Bt $20 \mu \mathrm{g}$ and CT $10 \mu \mathrm{g}$ & $4 / 4$ \\
\hline
\end{tabular}

Sensitizing inoculations were performed weekly (5 times) for 35 days. Results of PCA test were expressed in number of mice whose sera indicated a spot larger than $5 \mathrm{~mm}$ (Four mice were used in each group). Bt: Bt antigen, CT: cholera toxin.

relatively short sensitization period of 35 days ( 5 times at an interval of 7 days).

To examine the dose-dependent effect of Bt antigen and adjuvant $\mathrm{CT}$ on induction of Bt antigen-specific IgE response, different dosages of $\mathrm{Bt}$ antigen and $\mathrm{CT}$ were co-administered and serum $\mathrm{IgE}$ responses were determined by ELISA method for the specific IgE (Fig. 3). The mice inoculated with $\mathrm{Bt} / \mathrm{CT}$ mixture showed elevated levels of specific $\mathrm{IgE}$ on day 35 in a dose-dependent manner of $\mathrm{Bt}$ antigen and $\mathrm{CT}$. Positive responses in PCA test were observed with 1.0-10 $\mu \mathrm{g}$ of CT inoculated with $\mathrm{Bt}$ antigen $(20 \mu \mathrm{g})$, but not with $0.1 \mu \mathrm{g}$ of $\mathrm{CT}$ inoculated with the same antigen (data not shown).

Finally, the production of specific IgE was monitored for a long period of 24 weeks without previous priming immunization and coadministration of CT. As shown in Fig. 4, specific serum IgE levels gradually elevated by week 16 throughout the course of inoculation, although the levels were significantly lower than the IgG levels in the serum of mice inoculated with $\mathrm{Bt} / \mathrm{CT}$ mixture.

Elevation of total serum IgE by inoculation of Bt antigen: The total serum IgE levels measured in the indicated groups of mice inoculated intranasally with $\mathrm{Bt}$ antigen, $\mathrm{CT}$ and $\mathrm{Bt} / \mathrm{CT}$ mixture are represented in Fig. 5. Non-specific total IgE levels also elevated significantly in the sera of mice inoculated with Bt/CT mixture on day 35 .

Eosinophil count in Bt inoculated mice: Total counts of leukocyte 
a

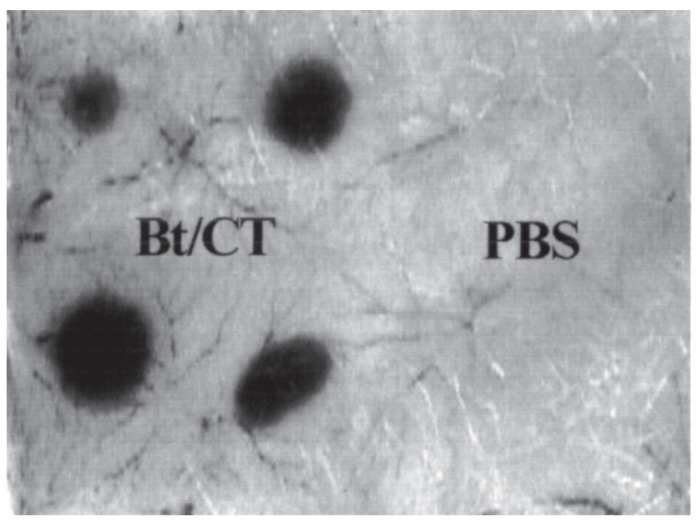

b

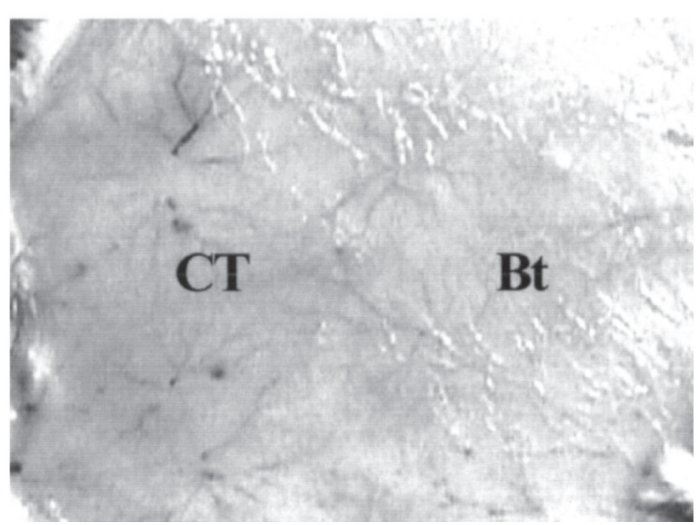

Fig. 2 - PCA responses in groups indicated of mice (in Table 2) which were co-inoculated with Bt antigen and $\mathrm{CT}$ as a mucosal adjuvant. (a) Response of respective mice (four in each group) inoculated with the mixture of Bt $(20 \mu \mathrm{g})$ and CT $(10 \mu \mathrm{g})$ and PBS as a control. (b) Response of respective mice (four in each group) inoculated with CT $(10 \mu \mathrm{g})$ only or Bt $(20 \mu \mathrm{g})$ only. Sensitizing inoculations were performed weekly ( 5 times) for 35 days. Blue spots were only observed with the sera sensitized with Bt/CT mixture. Bt: Bt antigen, CT: cholera toxin.
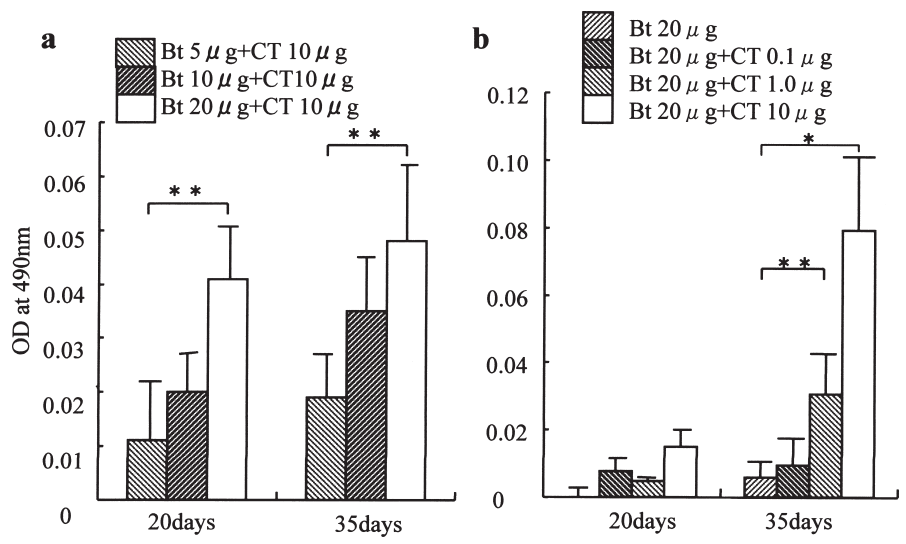

Fig. 3 - Bt-specific IgE responses estimated by ELISA in mice inoculated with Bt antigen and choleratoxin (CT). Sensitizing inoculations were performed weekly (5 times) for 35 days. Data were expressed as mean OD values for days 20 and 35 after subtracting background OD values of non-inoculated mice. Four mice were used in each group and vertical bars show standard error values. (a) IgE responses against different dosages of $\mathrm{Bt}$ antigen. (b) IgE responses against different dosages of CT. $* p<0.01, * * p<0.05$

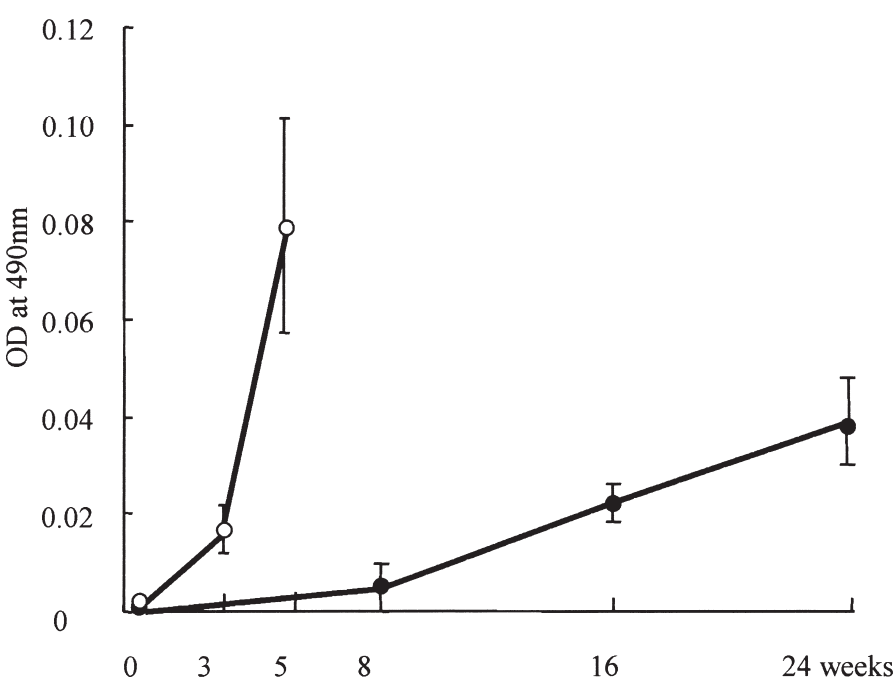

Fig. 4 - Specific IgE responses by long-term intranasal inoculation of Bt antigen without priming immunization and co-administration of mucosal adjuvant. The mice were inoculated with Bt antigen $(20 \mu \mathrm{g})$ alone weekly for 24 weeks (closed circles). IgE response by inoculation of Bt antigen $(20 \mu \mathrm{g})$ co-administered with cholera toxin $(\mathrm{CT} ; 10 \mu \mathrm{g})$ for 5 weeks (open circles) was also represented for comparison. Data were expressed as mean OD values after subtracting background OD values of non-inoculated mice. Four mice were used in each group and vertical bars show standard error values.

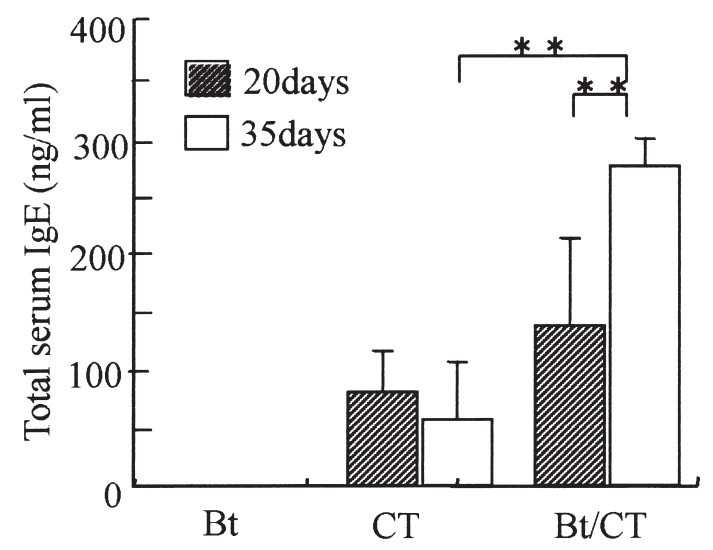

Fig. 5 - Total serum IgE in mice inoculated with Bt antigen with or without co-administration of cholera toxin (CT). Data were expressed as mean total IgE values for days 20 and 35 after subtracting background values of non-inoculated mice. Four mice were used in each group and vertical bars show standard error values. Sensitizing inoculations were performed weekly ( 5 times) for 35 days. Bt, CT: Mice inoculated with Bt antigen $(20 \mu \mathrm{g})$ or CT $(10 \mu \mathrm{g})$. Bt/CT: Mice inoculated with mixture of Bt antigen and CT. ** $p<0.05$

and ratios of differential counts of eosinophils in peripheral blood were also monitored (Fig. 6). Although leukocytes counts were not so different among the groups of mice throughout the experiments, the percentages of peripheral blood eosinophils increased significantly in the mice exposed to $\mathrm{Bt} / \mathrm{CT}$ mixture.

Immunoblot analysis on allergens in the Bt extract: The major allergenic components in the Bt extract were analyzed for their reactivity to IgE antibodies induced by Bt/CT inoculation. As shown in Fig. 7, the immunoblot analysis showed that more than eight polypeptide 


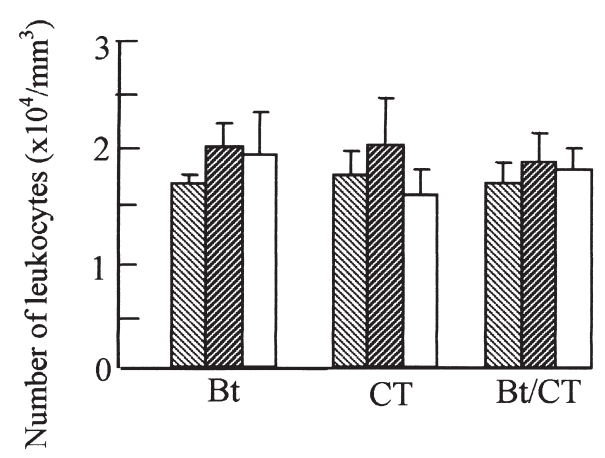

b

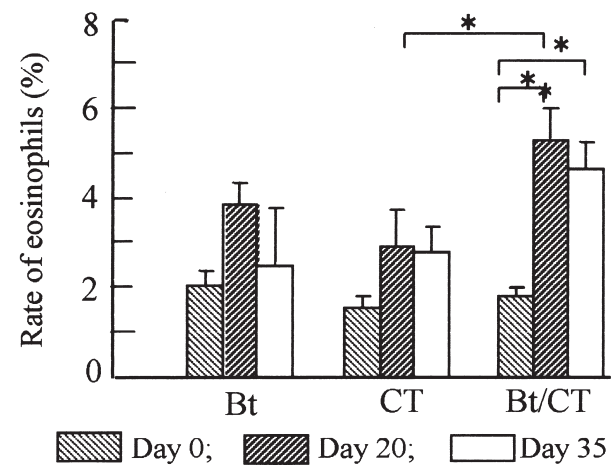

Fig. 6 - Number of leukocytes and rate of eosinophils in mice inoculated with Bt antigen with or without cholera toxin (CT). (a) Number of total leukocytes. (b) Rate of peripheral eosinophils. Mice were sensitized by intranasal inoculation with $\mathrm{Bt}$ antigen $(\mathrm{Bt} ; 20 \mu \mathrm{g}), \mathrm{CT}$ $(10 \mu \mathrm{g})$, and $\mathrm{Bt} / \mathrm{CT}$ mixture $(\mathrm{Bt} / \mathrm{CT})$. Sensitizing inoculations were performed weekly (5 times) for 35 days. Four mice were used in each group and mean values with standard error values (vertical bars) on days 0,20 and 35 are represented. $* p<0.05$ a

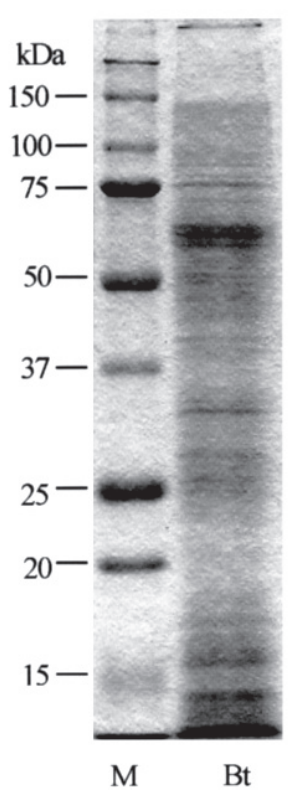

b

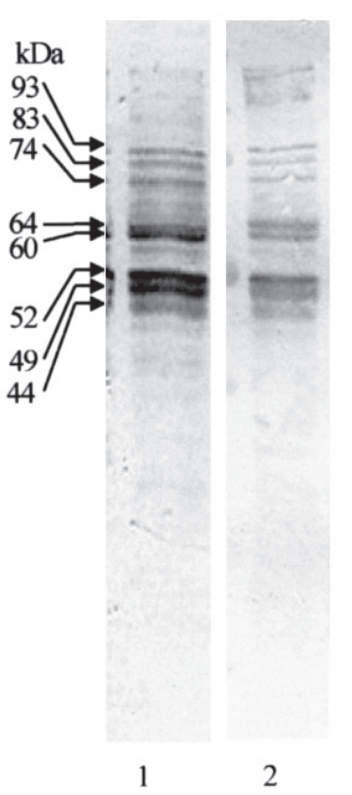

Fig. 7 - SDS-PAGE (a) and immunoblotting patterns (b) of Bt antigen. M: marker proteins; Bt: Bt antigen; 1 and 2: Representative immunoblotting patterns with mouse sera sensitized with mixture of $\mathrm{Bt}$ antigen and cholera toxin (CT) weekly for 35 days. The estimated molecular weights of main bands in $\mathrm{kDa}$ are indicated with arrows. components in the extract are reactive to the IgE antibodies. Five bands at position corresponding to molecular weights $64,60,52,49$, and 44 $\mathrm{kDa}$ were relatively strong in their reactivity.

In Fig. 8, immunoblot patterns were compared between the sera from mice sensitized with $\mathrm{Bt} / \mathrm{CT}$ mixture and those from mice sensitized with $\mathrm{Bt}$ antigen alone for a long period of over 24 weeks. The appearance of bands with serum sensitized only with Bt antigen was significantly weaker than that of bands with serum inoculated with Bt/CT mixture. Furthermore, the patterns of antigenic recognition by serum sensitized only with $\mathrm{Bt}$ antigen varied from those sensitized with $\mathrm{Bt} / \mathrm{CT}$ mixture; some bands including major bands at the $44-52 \mathrm{kDa}$ position were absent in the pattern with the serum exposed only to Bt antigen.

Fig. 9 represents SDS-PAGE patterns of extracts from Dermatophagoides pteronyssinus (Dp), Tokunagayusurika akamusi (Ta) and Chironomus yoshimatsui $(\mathrm{Cy})$ and its cross-reactivity to the sera sensitized with Bt/CT mixture. Scarce but notable bands were observed only with the extract of D. pteronyssinus and mouse anti-Bt IgE antibodies induced.

\section{DISCUSSION}

B. tropicalis is a common mite species in the living environment of humans in tropical and subtropical regions. The mites and mite-related antigens have frequently been found in house dust in these areas and it has been indicated that the patients with allergic diseases, such as asthma and atopic dermatitis, respond strongly to Bt antigen in skin-prick test, suggesting the presence of allergen(s) which induces IgE antibodies specific to $B$. tropicalis antigen ${ }^{8,15,25}$. The experimental study to identify

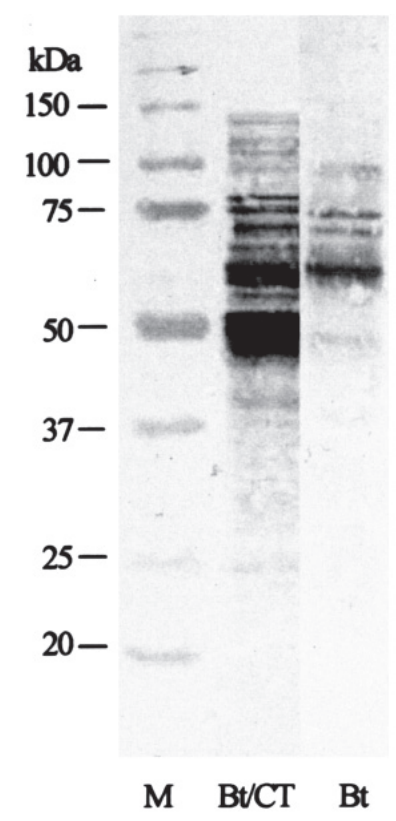

Fig. 8 - Immunoblotting patterns of Bt antigen to mouse sera sensitized with Bt antigen. M: marker protein, $\mathrm{Bt} / \mathrm{CT}$ : response of mice sensitized with $\mathrm{Bt} / \mathrm{CT}$ mixture, $\mathrm{Bt}$ : response of mice sensitized by long term inoculation of $\mathrm{Bt}$ antigen alone. The mice inoculated only with $\mathrm{Bt}$ antigen were received frequent administration of the antigen for a long period (weekly for 24 weeks) without co-administration of cholera toxin (CT) as a mucosal adjuvant. On the other hand, the mice sensitized with Bt/CT were received the mixture weekly for 35 days. The immunoblotting patterns in those mice are compared in the figure. 
a

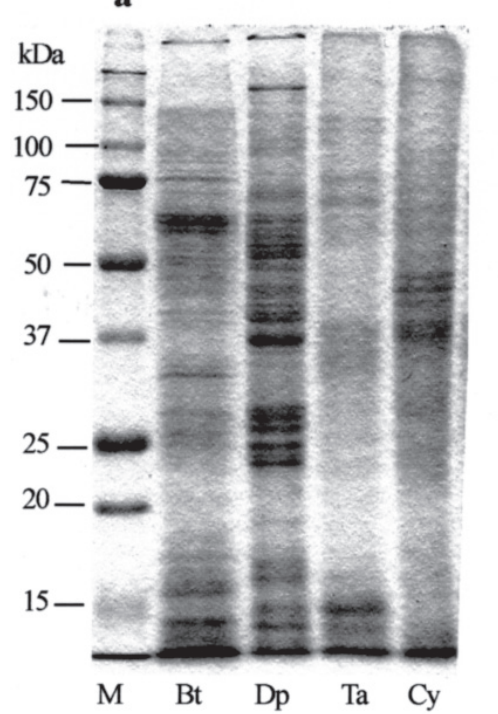

b

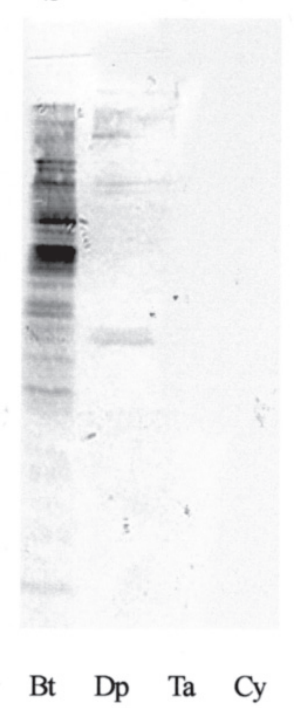

Fig. 9 - SDS-PAGE (a) and immunoblotting patterns (b) of various extracts from mites and chironomid species to mouse sera sensitized with Bt/CT mixture. M: marker. Bt: Blomia tropicalis, Dp: Dermatophagoides pteronyssinus, Ta: Tokunagayusurika akamusi, Cy: Chironomus yoshimatsui

the antigen(s) having the potential as allergen(s) in the mite components may be important in developing a useful diagnostic antigen for allergic diseases in these regions.

However, there were few experimental studies with animal model to induce Bt-specific IgE antibodies by administration of Bt antigen. In their study to induce oral tolerance of $\operatorname{IgE}$ response to B. tropicalis, SATO et al. demonstrated that IgE levels were markedly increased in mice by subcutaneous immunization of Bt antigen ${ }^{24}$. In the present study, the authors have first demonstrated that $B$. tropicalis-derived antigens could systematically induce allergic responses in mice by nasal route, providing the direct evidence that the mite antigens could function as potential allergens in vivo if administered properly.

A notable increase in $\mathrm{IgE}$ levels, specific and non-specific for $\mathrm{Bt}$ antigen, was recognized by intranasal inoculation of the antigen following the priming subcutaneous immunization of the same antigen or coadministration of $\mathrm{CT}$ as a functional mucosal adjuvant. Intranasal inoculation of the $\mathrm{Bt}$ antigen without priming sensitization, however, seemed to be insufficient for the induction of effective IgE responses. The production of $\mathrm{IgE}$ antibodies could not be confirmed when mice were exposed to Bt antigen alone for a short period. The administration of Bt antigen without priming immunization and adjuvant CT induced low-level specific IgE, only when the antigen was administered many times for a long period (24 times over 24 weeks). Using the extract of $D$. farinae, ISHII et al. have reported that increased frequency and administration duration, as well as the doses of antigens, could provide the mite antigens with the ability to function to prime the allergic immune responses ${ }^{12}$. The results also indicated that Bt antigens could function as allergens with potentials to induce an allergic condition if the antigens were provided with particular conditions i.e., frequency, dose, route, priming sensitization and adjuvant.
Generally, it is considered that induction of immune responses through a mucosal membrane is difficult when the antigen is administered without any effective adjuvant. Enterotoxin of Vibrio cholera is known to have high affinity for $\mathrm{G}_{\mathrm{M} 1}$-ganglioside on the $\mathrm{M}$ cells of mucosal lymphoid tissues ${ }^{17}$, and it is an effective mucosal adjuvant to deliver antigen to mucosal lymphoid tissues and to prime immune response through the mucosal membrane. Cholera toxin (CT), therefore, was used as the potent mucosal adjuvant in the present study. Intranasal inoculation of Bt antigen co-administered with CT induced Bt antigen-specific IgE antibody response without prior priming immunization. In the mice, elevation of total serum IgE level, as well as increase of peripheral blood eosinophil counts, was accompanied by the production of specific IgE, indicating a systemic allergic condition in the mice. Although it is unclear whether co-inoculation of the mucosal adjuvant is absolutely necessary for induction of $\operatorname{IgE}$ response through mucosa or not, the present observations in which $\mathrm{Bt} / \mathrm{CT}$ mixture augmented strong IgE responses suggest that the CT functioned to increase allergenicity of $\mathrm{Bt}$ antigen in the mice. In a similar experiment by HIRAI et al., using extract from cedar pollen, it was also reported that co-administration with CT was essential to induce specific IgE production against the antigen ${ }^{9}$. In addition, the effect of CT to augment allergenicity of $\mathrm{Bt}$ antigen was dose-dependent in the present ELISA assay, as it was in the experiment by HIRAI et al. ${ }^{9}$.

The strong immunostimulating effect of CT is attractive for a new mucosal vaccine strategy in which $\mathrm{CT}$ is expected to be an effective adjuvant to deliver vaccine antigen to the mucosal immune system ${ }^{11,16,28}$. On the other hand, it has been indicated that immunization through mucosal tissue often induces an allergic response ${ }^{11}$. The present study also indicates the possibility that vaccine antigen, when co-administered with $\mathrm{CT}$ as adjuvant, may induce an allergic response against the vaccine antigen. Induction of serum IgE by mucosal administration of antigen mixed with CT, however, may depend in part on the nature of antigen because while some antigens induce IgE production others do not (ARAKAWA, unpublished data). Studies on the nature of antigens and immune responses against the antigens through mucosal tissue are important not only for the development of effective mucosal vaccines, but also for prevention of allergic diseases through mucosa.

Immunoblotting analysis using the sera with high $\operatorname{IgE}$ levels detected more than 8 bands that reacted with the $\operatorname{IgE}$ antibodies at a relatively high molecular weight position of over $40 \mathrm{kDa}$. Among the reactive components, five components of molecular weights 64, 60, 52, 49 and $44 \mathrm{kDa}$ were clearly recognized between mice sera sensitized with $\mathrm{Bt} /$ CT mixture. In their study using B. tropicalis extract and asthmatic patient sera, RAMOS et al. have pointed out that an important candidate allergen in the mite extract was $66 \mathrm{kDa}$ polypeptide component which was identical to mite paramyosin ${ }^{22}$. The authors also detected a similar band at $64 \mathrm{kDa}$ position and the component was found to be reactive to anti-paramyosin antibody, suggesting that the component is identical to the mite paramyosin (date not shown). The isolation and sequence of the component should be further investigated so as to establish it as a good candidate for the diagnostic antigen for the mite allergy.

Finally, the cross reaction with other species of dust mite, namely D. pteronyssinus, and chironomid species, which are known as important insect inhalant allergens were almost negligible in the present study, although a cross reaction was faintly observed between $D$. pteronyssinus extract and antisera sensitized with Bt/CT mixture. 
In conclusion, the present study has significance as the first evidence that $\mathrm{Bt}$ antigen elicited specific IgE production in mice through mucosal membrane. Particularly, it is noticeable that the mucosal adjuvant CT inoculated with Bt antigen elicited stronger responses of Bt-specific IgE antibodies in a relatively short duration. The immunoblot analysis identified that the component at about 44-64 kDa position was nominated as a predominant and functional allergen in the mite extract. Using the induced $\operatorname{IgE}$ antibodies, further study to identify and clarify the allergenic component, in respect to its immunologic properties and identity with other mite allergens, is necessary.

\section{RESUMO}

\section{Sensibilização intranasal com antígenos de Blomia tropicalis induz respostas alérgicas em camundos caracterizadas pela elevada contagem de soro IgE antígeno-específico e não específico e de eosinófilos no sangue periférico}

Para avaliar a capacidade alergizante do antígeno da Blomia tropicalis (Bt) a produção de $\operatorname{IgE}$ específica e não específica a antígeno $B t$ foi monitorada em camundongos BALB/c após exposição ao antígeno por via nasal. Foi evidenciado que $B t$ contem um alérgeno funcional em seus componentes. Os componentes alergênicos entretanto, quando administrados por via intra-nasal, sem qualquer adjuvante, não induzem resposta $\operatorname{IgE}$ durante um pequeno período. Por outro lado, a inoculação intra-nasal de antígenos Bt aumentou a resposta sérica de $\operatorname{IgE}$ em camundongos pré-tratados por uma injeção inicial sensibilizante subcutânea aos mesmos antígenos. A inoculação do antígeno Bt sem as injeções sensibilizantes iniciais induziu a produção de anticorpos $\operatorname{IgE}$ somente quando o antígeno foi administrado de maneira contínua, por um período longo de mais de 24 semanas. Mesmo quando as injeções sensibilizantes iniciais foram ausentes, o antígeno $B t$ inoculado com a toxina de cólera (CT) como adjuvante mucoso também aumentou de maneira significante a resposta IgE antígeno específica do $B t$ dependendo da dose de CT administrada conjuntamente. O presente estudo também demonstrou que camundongos inoculados com antígeno $\mathrm{Bt} / \mathrm{CT}$ mostram aumento do nível IgE não específico no soro e médias de eosinófilos no sangue periférico sem qualquer elevação da contagem total de leucócitos. A análise por Immunoblot demonstrou cinco principais componentes antigênicos reativos aos anticorpos IgE induzidos. Estes componentes na posição 44-64 kilodaltons foram considerados importantes antígenoscandidatos para o diagnóstico da alergia relacionada ao ácaro.

\section{REFERENCES}

1. ARLIAN, L.G.; BERNSTEIN, D.; BERNSTEIN, I.L. et al. - Prevalence of dust mites in the homes of people with asthma living in eight different geographic areas of the United States. J. Allergy clin. Immunol., 90: 292-300, 1992.

2. ARRUDA, L.K.; RIZZO, M.C.; CHAPMAN, M.D. et al. - Exposure and sensitization to dust mite allergens among asthmatic children in São Paulo, Brazil. Clin. exp. Allergy, 21: 433-439, 1991

3. BARRETO, B.A.P.; DAHER, S.; NASPITZ, C.K. \& SOLE, D. - Specific and non-specific nasal provocation tests in children with perennial allergic rhinitis. Allergol. Immunopath., 29: 255-263, 2001.

4. CARABAllo, L.; AVJioglu, A.; MARRUGO, J.; PUERTA, L. \& MARSH, D. Cloning and expression of complementary DNA coding for an allergen with common antibody-binding specificities with three allergens of the house dust mite Blomia tropicalis. J. Allergy clin. Immunol., 98: 573-579, 1996.
5. CARABALlO, L.; PUERTA, L.; MARTINEZ, B. \& MORENO, L. - Identification of allergens from the mite Blomia tropicalis. Clin. exp. Allergy, 24: 1056-1060, 1993.

6. CHOU, T.Y.; WU, K.Y.; SHIEH, C.C. \& WANG, J.Y. - The clinical efficacy of in vitro allergen-specific IgE antibody test in the diagnosis of allergic children with asthma. Acta paediatr. Tw., 43: 35-39, 2002.

7. FERNANDEZ-CALDAS, E.; PUERTA, L.; MERCADO, D.; LOCKEY, R.F. \& CARABALlO, L.R. - Mite fauna, Der $p 1, \operatorname{Der} f 1$ and Blomia tropicalis allergen levels in a tropical environment. Clin. exp. Allergy, 23: 292-297, 1993.

8. FERRANDIZ, R.; CASAS, R. \& DREBORG, S. - Sensitization to Dermatophagoides siboney, Bromia tropicalis, and other domestic mites in asthmatic patients. Allergy, 51: 501-505, 1996.

9. HIRAI, T.; HASHIGUCHI S.; TORIGOE, N. et al. - Intranasal sensitization of Japanese cedar pollen by the co-administration of low doses of cholera toxin but not its recombinant B subunit to mice. Microbiol. Immunol., 44: 259-266, 2000.

10. HURTADO, I. \& PARINI, M. - House dust mites in Caracas, Venezuela. Ann. Allergy, 59: 128-130, 1987.

11. ISAKA, M.; YASUDA, Y.; KOZUKA, S. et al. - Induction of systemic and mucosal antibody responses in mice immunized intranasally with aluminum-non-adsorbed diphtheria toxoid together with recombinant cholera toxin B subunit as an adjuvant. Vaccine, 18: 743-751, 2000.

12. ISHII, A.; MATHUHASHI, T.; MIYAMOTO, J. \& SASA, M. - Production of homocytotropic antibody in guinea pigs inhalated with an extract of the house dust mite, Dermatophagoides farinae. Jap. J. exp. Med., 43: 25-32. 1973.

13. KHOO, J.; SHEK, L.; KHOR, E.S.H.; WANG, D.Y. \& LEE, B.W. - Pattern of sensitization to common environmental allergens amongst atopic Singapore children in the first 3 years of life. Asian Pac. J. Allergy Immunol., 19: 225-229, 2001.

14. KISHIMOTO, T. \& HIGA, Y. -The fauna of mites in a concrete apartment house in Okinawa Prefecture. Ann. Rep. Okinawa Prefect. Inst. Publ. Hlth., 25: 41-47, 1991. (In Japanese).

15. KUO, I.C.; YI, F.C.; CHEONG, N. et al. - Sensitization to Blomia tropicalis and Dermatophagoides pteronyssinus - A comparative study between Singapore and Taiwan. Asian Pac. J. Allergy Immunol., 17: 179-188, 1999.

16. LYCKE, N. \& HOLMGREN, J. - Strong adjuvant properties of cholera toxin on gut mucosal immune responses to orally presented antigens. Immunology, 59: 301-308, 1986.

17. MERRITT, E.A.; SARFATY, S.; VAN DEN AKKER, F. et al. - Crystal structure of cholera toxin B-pentamer bound to receptor $\mathrm{G}_{\mathrm{M} 1}$ pentasaccharide. Protein Science, 3: 166-175, 1994.

18. MIYAMOTO, T.; OSHIMA, S.; DOMAE, A. et al. - Allergenic potency of different house dust in relation to contained mites. Ann. Allergy, 28: 405-412, 1970.

19. MORI, J.C.; PIRES, M.C.; GALVÃO, C.E.S. et al. - Determination of Blomia tropicalisspecific IgE and IgG subclass in atopic dermatitis patient. Allergy, 56: 180-184, 2001.

20. OSHIMA, S. - Observations of floor mites collected in Yokohama. I. On the mites found in several schools in summer. Jap. J. sanit. Zool., 15: 233-244, 1964. (In Japanese).

21. PUERTA, L.; FERNANDEZ-CALDAS, E.; MERCADO, D.; LOCKEY, R.F. \& CARABALLO, L.R. - Sequential determinations of Blomia tropicalis allergens in mattress and floor dust sample in a tropical city. J. Allergy clin. Immunol., 97: 689691, 1996.

22. RAMOS, J.D.A.; TEO, A.S.M.; OU, K.L. et al. - Comparative allergenicity studies of netive and recombinant Blomia tropicalis Paramyosin (Blo t 11). Allergy, 58: 412419, 2003. 


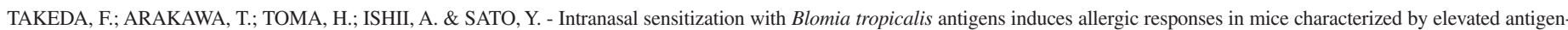
specific and non-specific serum IgE and peripheral blood eosinophil counts. Rev. Inst. Med. trop. S. Paulo, 46(1):1-8, 2004.

23. RUEDA, L.M. - House dust mites (Acari) in Malaysia. Philipp. Ent., 6: 428-434, 1985.

24. SATO, M.N.; OLIVEIRA, C.R.; FUTATA, E.A. et al. - Oral tolerance induction to Dermatophagoides pteronyssinus and Blomia tropicalis in sensitized mice: occurrence of natural autoantibodies to immunoglobulin E. Clin. exp. Allergy, 32: 1667-1674, 2002.

25. STANALAND, B.E.; FERNANDEZ-CALDAS, E.; JACINTO, C.M.; TRUDEAU, W.L. \& LOCKEY, R.F. - Sensitization to Blomia tropicalis; skin test and cross-reactivity studies. J. Allergy clin. Immunol., 94: 452-457, 1994.

26. TOMA, T.; MIYAGI, I.; KISHIMOTO, M.; NAGAMA, T. \& TAMANAHA, I. - Fauna and seasonal appearances of mites in house dusts collected from the residences including asthmatic children in Okinawa Prefecture, Ryukyu Archipelago. Jap. J. sanit. Zool., 44: 223-235, 1993. (In Japanese).
27. TOMA, T.; MIYAGI, I.; TAKEDA, F.; KISHIMOTO, R. \& AHAGON, A. - Mite fauna and abundance in dust collected from bedding and bedrooms in Okinawa, Japan. Med. Entomol. Zool., 49: 309-319, 1998.

28. TSUJI, N.; SUZUKI, K.; KASUGA-AOKI, H. et al. - Intranasal immunization with recombinant Ascaris suum 14-kDa antigen coupled with cholera toxin B subunit induces protective immunity to A. suum infection in mice. Infect. Immun., 69: 72857292, 2001.

29. VAN BRONSWIJK, J.E.M.H.; DE COCK, A.W.A.M. \& OSHIMA, S. - The genus Blomia oudemans (Acari: Glycyphagidae). I. Description of Blomia tropicalis sp. n. from house dust in tropical and sub-tropical regions. Acarologia, 15: 477-489, 1973.

Received: 24 September 2003

Accepted: 12 January 2004 